\title{
Tax-Loss Selling and the Year-End Behavior of Dow Jones Stocks
}

\author{
Max Gold \\ BlackRock Alternative Advisors \\ Seattle, WA 98101, USA \\ Tel: 1-206-613-6772Ｅ-mail: Max.Gold@blackrock.com \\ Jeff Levere \\ Department of Economics, Pomona College \\ Claremont, CA 91711, USA \\ Tel: 1-914-275-2548Ｅ-mail: jeffrey.levere@pomona.edu
}

\author{
Gary Smith (Corresponding author) \\ Department of Economics, Pomona College \\ Claremont, CA 91711, USA
}

Tel: 1-909-624-7935 E-mail: gsmith@pomona.edu

\author{
Received: November 2, 2012 \\ Accepted: November 18, 2012 \\ Online Published: January 7, 2013 \\ doi:10.5430/afr.v2n1p40 \\ URL: http://dx.doi.org/10.5430/afr.v2n1p40
}

\begin{abstract}
A capital gain or loss only has tax consequences if the asset is sold. This tax rule creates an incentive for realizing losses but not gains. If investors implement this tax-harvesting strategy, there should be a surge in the year-end sales of stocks whose prices have declined during the year, and additional downward pressure on their prices. Previous studies have found evidence of volume and price effects, particularly for small stocks. In contrast, our analysis of the components of the Dow Jones Industrial Average finds abnormally high December volume for depressed stocks, but little or no effect on prices - evidently because of their liquidity.
\end{abstract}

Keywords: Tax-loss selling, January effect, Window dressing

\section{Introduction}

In the United States, there is a tax incentive to realize capital losses by selling stocks that have experienced price declines, an incentive that is clearest at the end of the calendar year. In theory, year-end tax sales should increase the volume of trading in depressed stocks and might further depress their prices. In practice, the U.S. stock market may be dominated by pension funds, nonprofits, and other institutions that do not benefit from tax harvesting and by mutual funds and individual investors who should care about tax harvesting, but do not. In addition, even if year-end tax sales do occur, there should be little effect on the prices of very liquid stocks.

Our research question is whether the volume and price effects that have been reported previously for broad stock categories also hold for stocks that are widely followed, heavily traded, and very liquid. To investigate this question, we look for evidence of tax harvesting for the blue chip stocks that comprise the Dow Jones Industrial Average.

\subsection{Tax-Loss Selling}

A complex set of tax rules apply to short-term and long-term capital gains and losses. For our purposes, the most important tax rules are that net realized capital gains are fully taxable, with long-term gains (on assets held for more than one year) taxed at a lower rate than short-term gains, while net realized losses can be used to a limited extent — up to $\$ 3,000$, or $\$ 1,500$ if married but filing separately - to reduce taxable income. When an investor dies, the basis is revised to the current market value, thereby eliminating all unrealized gains and losses. Unused carryover losses also expire with the taxpayer's death.

The lower tax rate on long-term gains creates a clear incentive to defer the realization of gains until they become 
lightly taxed long-term gains. Even after they become long-term gains, there are continuing benefits from not selling the asset so that dividends and capital gains can be earned on the taxes that are deferred-and then vanish at death. For assets with capital losses, in contrast, there are tax benefits from selling. Investors cannot make money by losing money; but once a loss occurs, it can be profitable to realize the loss and invest the tax savings. There is a compelling incentive to realize losses in the tax year they occur so that the tax value of the losses can begin earning dividends and capital gains as soon as possible, and does not disappear when the investor dies (Branch, 1977; Smith and Smith, 2008).

Several studies have found evidence that stocks that have done poorly during the year experience abnormal selling pressure at the end of the year, which increases the volume of trading and may depress prices. This is particularly true for small-cap stocks, which are less liquid and more volatile and consequently are more likely to offer opportunities for tax harvesting (Dyl, 1977; Givoly and Ovadia, 1983; Reinganum, 1983; Roll, 1983; D’Mello, Ferris, and Hwang, 2002).

\subsection{Window Dressing}

Window dressing refers to the institutional practice of selling poorly performing stocks shortly before a reporting period ends, for example, at the end of a calendar year, in order to avoid disclosing unfortunate investments that might damage the institution's credibility and scare away customers.

Window dressing, like tax-loss selling, predicts an increase in year-end trading of poorly performing stocks, and possible downward pressure on prices. Several papers have found evidence consistent with window dressing by mutual funds, hedge funds, and investment advisors (Haugen and Lakonishok, 1988; Maxwell, 1998; Meier and Shaumburg, 2004). However, it is difficult to determine if a year-end surge in the trading of depressed stocks is due to tax-loss selling or window dressing because we generally do not know if the sales were by tax-sensitive individuals or tax-insensitive institutions (Poterba and Weisbrenner, 2001). However, Starks, Young, and Zheng (2006) find evidence of abnormal end-of-year volume for depressed municipal bond closed-end funds, which are held primarily by tax-sensitive investors, but not for the bonds in the funds' portfolios, which indicates that tax harvesting is more important than window dressing.

\section{Methodology}

There are potentially significant confounding effects for stocks in the S\&P 500 because S\&P 500 index funds must buy and sell stocks that are added or dropped from the index (Jain 1987; Denis, McConnell, Ovtchinnikov, and Yu, 2003). These index effects are less worrisome for the Dow Jones Industrial Average because there are fewer changes, the stocks are more liquid, and Dow Index funds are much smaller than S\&P index funds.

We looked at the stocks in the Dow Jones Industrial Average from 1971 through 2011. The daily volume and prices were obtained from the Center for Research in Security Prices (CRSP) database. Daily data for the Fama-French factors were taken from Kenneth French's Dartmouth web site (2011).

Each year, we looked at the 30 stocks that were in the Dow on the first trading day of that year, for example January 4, 1971, and then tracked their daily share volume and closing prices until the last trading day in December. There were 27 changes in the composition of the Dow during these 40 years. When a Dow substitution was made, we continued to follow the stock that was in the Dow on the first trading day of the year until the end of the year. Stocks that were substituted into the Dow during the year were included in our analysis starting on the first trading day of the following year.

General Foods was dropped from the Dow in November 1985 when it was acquired by Philip Morris; Owens-Illinois was dropped in March 1987 after a leveraged buyout by Kohlberg Kravis Roberts. In each case, the stock was no longer publicly traded and there are consequently no price data for the remainder of the year. For these two years, we only looked at the other 29 stocks in the Dow.

There is no unambiguous way of identifying the most attractive candidates for year-end tax harvesting. Dyl (1977) compared prices in November of each year to prices in January of that year. We used a slightly different rule. If the closing price on the last trading day in November was substantially below the average price so far that year, then the stock was characterized as a Depressed stock; otherwise, it was labeled an Other stock. A simple comparison of November and January prices does not distinguish between a price that rose during the year before falling and a price that fell during the year before rising. A comparison of the end-of-November price with the average price so far that year is an appealing indicator of whether people who bought the stock during the year are likely to have short-term capital losses that might be harvested profitably. 
Dyl defined a slumping stock as one whose price is down 20 percent. We used 10,20 , and 30 percent cutoffs to gauge the robustness of our results.

\subsection{December Trading Volume}

Our procedure for measuring abnormal trading volume was similar to Dyl (1977). For each Dow stock $i$, average daily volume in month $t$ is

$$
V_{i t}=\frac{S_{i t}}{n_{t}}
$$

where $S_{i t}$ is the total number of shares of stock $i$ traded during month $t$ and $n_{t}$ is the number of trading days in that month. A stock's relative volume is the ratio of daily volume in month $t$ to the stock's average daily volume over the preceding 12 months:

$$
Y_{i t}=\frac{V_{i t}}{\left(\sum_{j=t-1}^{t-12} V_{i j}\right) / 12}
$$

For the Dow stocks as a whole, average daily volume is

$$
D_{t}=\frac{\sum_{i=1}^{30} S_{i t}}{n_{t}}
$$

and relative daily volume is

$$
X_{i t}=\frac{D_{t}}{\left(\sum_{j=t-1}^{t-12} D_{j}\right) / 12}
$$

To investigate the relationship between stock $i$ 's relative daily volume and the Dow's relative daily volume, we estimate this equation using data for all months when the stock was part of the Dow, other than December:

$$
Y_{i t}=\alpha_{i}+\beta_{i} X_{t}+\varepsilon_{i t}
$$

The Dow volume variable accounts for market-wide events that affect overall trading volume. The regressions exclude December of each year because tax-loss selling may effect year-end trading.

Abnormal daily volume for stock $i$ is the difference between actual and predicted volume using the parameter estimates $a_{i}$ and $b_{i}$ :

$$
e_{i t}=Y_{i t}-\left(a_{i}+b_{i} X_{t}\right)
$$

Abnormal daily volume for stock $i$ is measured relative to the average daily volume for this stock over the preceding 12 months. For example, an abnormal volume of 0.10 means that daily volume exceeded expected daily volume by an amount that is equal to 10 percent of the size of average daily volume over the preceding 12 months.

A difference-in-means t-test was used to compare the average abnormal daily December volume for Depressed and Other stocks. We used a two-sided P value because we did not rule out a priori the possibility that volume is either higher or lower for Depressed stocks. We also calculated abnormal volume $e_{i t}$ on each trading day in December by using Equation (5) to compare actual relative volume on each day of December to the predicted relative volume.

\subsection{December Returns}

The second issue we considered was whether year-end selling had a significant effect on the prices of Depressed stocks. We calculated the percentage difference between the closing prices of each Dow stock on the first and last trading days in December. A difference-in-means $t$ test was used to compare the average percentage price changes for Depressed and Other stocks. Again, we used a two-sided P value.

We also calculated the daily December returns for two portfolios, a Depressed portfolio and an Other portfolio. On the last trading day of November of each year, the funds in the Depressed portfolio were divided equally among the depressed stocks and these stocks were held until the last trading day in December. A similar procedure was used for the Other portfolio. 
Any observed difference in December performance might be due to confounding factors, particularly momentum. To control for confounding factors, we used daily December data to estimate separate regressions for the Depressed and Other portfolios using the Fama-French (1993) three-factor model augmented by a momentum factor (Carhart 1997):

$$
\mathrm{R}=\alpha+\beta_{1} M K T+\beta_{2} S M B+\beta_{3} H M L+\beta_{4} W M L+\varepsilon
$$

where $\mathrm{R}$ is the return on the portfolio minus the Treasury bill rate; MKT is the value-weighted market return minus the Treasury bill rate (market factor); SMB is the average return on three small portfolios minus the average return on three large portfolios (size factor); HML is the average return on two value portfolios minus the average return on two growth portfolios (book-to-market factor); and WML is the average return on winner portfolios minus the average return on loser portfolios (momentum factor).

The market factor was included because macroeconomic variables such as unemployment and interest rates cause stock returns to be positively correlated. The size factor was included because small stocks tend to outperform large stocks (Banz 1981; Reinganum 1981). The value factor was included because stocks with high book-to-market ratios tend to outperform growth stocks (Rosenberg, Reid, and Lanstein, 1985). The momentum factor was included because stocks that have been doing well tend to outperform those doing poorly (Jegadeesh and Titman 1993). These factors may reflect risks that investors must be compensated for bearing (Fama and French, 1992) or they may be evidence of market inefficiencies (Lakonishok, Shliefer, and Vishny, 1994). Either way, the question here is whether the December performance of Depressed and Other stocks can be explained by these four factors.

\section{Results}

\subsection{December Trading Volume}

Table 1 compares the average abnormal daily December volume for Depressed and Other stocks using the 10\%, 20\%, and $30 \%$ cutoffs for identifying Depressed stocks. A difference-in-means t-test was used to compare average abnormal daily December volume for Depressed and Other stocks.

At all cutoffs $(10 \%, 20 \%$, and $30 \%)$, there was a substantial and statistically significant difference in the trading of Depressed stocks in December compared to Other stocks. This is consistent with a tax-based strategy of harvesting capital losses and postponing the realization of capital gains. Average abnormal volume for the Depressed stocks increases as the cutoff increases, which makes sense because tax harvesting is most profitable for stocks with the largest capital losses. Mean abnormal volume of 0.2520 means that the average amount by which daily December volume exceeded the expected daily volume was equal to 25.20 percent of the size of average daily volume over the preceding 12 months.

We also calculated the average abnormal volume on each trading day in December by using Equation 5 to compare actual relative volume on each day in December to the predicted relative volume. Figure 1, using a 20 percent cutoff, shows that, every day in December, Depressed stocks had positive abnormal volume, while Other stocks exhibited negative abnormal volume. (The gap on December 25 is due to the markets being closed on Christmas each year.)

\subsection{December Returns}

Table 2 shows the summary statistics for the December returns for the Depressed and Other stocks. The Depressed stocks performed slightly better, on average, than the Other stocks using a 10 percent or 20 percent cutoff, and substantially worse using a 30 percent cutoff. However, none of the differences were close to being statistically significant.

The estimated regression equations using the three Fama-French factors and a momentum factor are shown in Table 3. Perhaps most interestingly, the estimates of the intercept alpha, which measures the excess return, were relatively small and not statistically significant at the 5 percent level. Evidently, the small observed differences between the December returns for Depressed and Other stocks shown in Table 2 are easily explained by the Fama-French factors and the momentum factor.

The coefficients of the market factor are consistently positive and highly significant. The coefficients of the size factor are always negative (DJIA stocks tend to be large, so this is what we expected) and statistically significant at the 5 percent level in four of six cases. The coefficients of the book-to-market factor are always positive (Dow stocks tend to be value stocks, so this is what we expected), but only statistically significant at the 5 percent level for the Other stocks. The coefficients of the momentum factor are generally negative for the Depressed stocks and positive for the Other stocks. The one exception is Other stocks with a 30 percent cutoff, but the t-statistic is very small. This pattern in the momentum coefficients is unsurprising since the Depressed stocks had negative momentum and the Other stocks had positive momentum. 
It is interesting that, as gauged by $\mathrm{R}^{2}$ and the t-statistics, the regression model explains the daily variation in the Other returns much better than the Depressed returns.

\section{Conclusion}

Average abnormal daily December trading volume tended to be positive for Depressed stocks and negative for Other stocks, which is consistent with a tax-based strategy of harvesting capital losses and postponing the realization of capital gains. Window-dressing is an alternative explanation for the heavy trading of Depressed stocks in December; however, window-dressing is less able to explain the diminished trading in Other stocks. The window-dressing hypothesis suggests that trading should increase in December for both Depressed and Other stocks as institutions cleanse their portfolio's appearance by replacing losers with other stocks.

For the very liquid and closely followed stocks in the Dow Jones Industrial Average, these changes in trading volume evidently have little effect on prices. A difference-in-means t-test showed no statistically significant differences between the average December returns of Depressed and Other stocks, and a factor model showed no evidence of excess returns. The contrast between these conclusions and the results reported previously (for example, D’Mello, Ferris, and Hwang, 2002) are evidently because prices are less sensitive to changes in demand or supply for stocks that are widely followed, heavily traded, and very liquid.

Of course, many very liquid stocks are not in the Dow Jones Industrial Average. One avenue of future research is to use an explicit quantitative measure of liquidity to identify the most liquid stocks and to investigate whether the volume/price effects reported here are replicated.

\section{References}

Banz, R. (1981). The relationship between return and market value of common stocks. Journal of Financial Economics. 9, 3-18. http://dx.doi.org/10.1016/0304-405X(81)90018-0

Branch, B. (1977). A tax loss trading rule. Journal of Business. 50, 198-207. http://dx.doi.org/10.1086/295930

Carhart, M. (1997). On persistence in mutual fund performance. Journal of Finance. 52, 57-82. http://dx.doi.org/10.1111/j.1540-6261.1997.tb03808.x

D'Mello, R., Ferris S., Hwang C. (2003). The tax-loss selling hypothesis, market liquidity, and price pressure around the turn-of-the-year. Journal of Financial Markets. 6, 73-98. http://dx.doi.org/10.1016/S1386-4181(02)00023-X

Denis, D., McConnell, J., Ovtchinnikov, A., Yu, Y. (2003). S\&P additions and earnings expectations. Journal of Finance. 58, 1821-1840. http://dx.doi.org/10.1111/1540-6261.00589

Dyl, E. (1977). Capital gains taxation and year-end stock market behavior. Journal of Finance. 32, 165-175. http://dx.doi.org/10.1111/j.1540-6261.1977.tb03250.x

Fama, E., French, K. (1992). The cross-section of expected stock returns. Journal of Finance. 47, 427-465. http://dx.doi.org/10.1111/j.1540-6261.1992.tb04398.x

Fama, E., French, K. (1993). Common risk factors in the returns on bonds and stocks. Journal of Financial Economics. 33, 3-53. http://dx.doi.org/10.1016/0304-405X(93)90023-5

French, Kenneth R. (March 1, 2012). Data Library; [Online] Available: http://mba.tuck.dartmouth.edu/pages/faculty/ken.french/data_library.htm

Givoly, D., Ovadia, A. (1983). Year-end induced sales and stock market seasonality. Journal of Finance. 38, 171-185. http://dx.doi.org/10.1111/j.1540-6261.1983.tb03633.x

Haugen, R., Lakonishok, J. (1988). The Incredible January Effect. Homewood, Il: Dow Jones-Irwin.

Jegadeesh, N., Titman, S. (1993). Returns to buying winners and selling losers: Implications for stock market efficiency. Journal of Finance. 48, 65-91. http://dx.doi.org/10.1111/j.1540-6261.1993.tb04702.x

Lakonishok, J., Shliefer, A., Vishny, R. (1994). Contrarian investment, extrapolation, and risk. Journal of Finance. 49, 1541-1578. http://dx.doi.org/10.1111/j.1540-6261.1994.tb04772.x

Maxwell, W. (1998). The January effect in the corporate bond market: A systematic examination. Financial Management. 27, 18-30. http://dx.doi.org/10.2307/3666290

Meier, I., Schaumburg, E. (2004). Do funds window dress? Evidence for U.S. domestic equity mutual funds. Unpublished working paper, HEC Montreal and Kellogg School of Management. 
Poterba, J., Weisbenner, S. (2001). Capital gains tax rules, tax-loss trading, and turn-of-the year returns. Journal of Finance. 56, 353-368. http://dx.doi.org/10.1111/0022-1082.00328

Reinganum, M. (1981). Misspecification of capital asset pricing: Empirical anomalies based on earnings' yields and market values. Journal of Financial Economics. 9, 19-46. http://dx.doi.org/10.1016/0304-405X(81)90019-2

Reinganum, M. (1983). The anomalous stock market behavior of small firms in January. Journal of Financial Economics. 12, 89-104. http://dx.doi.org/10.1016/0304-405X(83)90029-6

Roll, R. (1983). Vas is das? The turn-of-the-year effect and the return premia of small firms. Journal of Portfolio Management. 9, 18-28. http://dx.doi.org/10.3905/jpm.1983.18

Rosenberg, B., Reid, K., Lanstein, R. (1985). Persuasive evidence of market inefficiency. Journal of Portfolio Management. 11, 9-17. http://dx.doi.org/10.3905/jpm.1985.409007

Smith, M., Smith, G. (2008). Harvesting capital gains and losses. Financial Services Review. 17, 309-321.

Starks, L., Yong, L., Zheng, L. (2006). Tax-loss selling and the January effect: Evidence from Municipal Bond Closed-End Funds. The Journal of Finance. 61, 3049-3067. http://dx.doi.org/10.1111/j.1540-6261.2006.01011.x

Table 1. Abnormal Daily December Volume, Depressed and Other Stocks

\begin{tabular}{|c|c|c|c|c|}
\hline & Number of Stocks & Mean & Standard Deviation & Two-sided P value \\
\hline \multicolumn{5}{|c|}{10 percent cutoff } \\
\hline Depressed Stocks & 320 & 0.1291 & 0.4425 & \multirow{2}{*}{$2.5 \times 10^{-13}$} \\
\hline Other Stocks & 908 & -0.0860 & 0.4370 & \\
\hline \multicolumn{5}{|c|}{20 percent cutoff } \\
\hline Depressed Stocks & 178 & 0.1765 & 0.3674 & \multirow{2}{*}{$2.1 \times 10^{-11}$} \\
\hline Other Stocks & 1050 & -0.0649 & 0.4515 & \\
\hline \multicolumn{5}{|c|}{30 percent cutoff } \\
\hline Depressed Stocks & 95 & 0.2520 & 0.3956 & \multirow{2}{*}{$4.1 \times 10^{-11}$} \\
\hline Other Stocks & 1133 & -0.0536 & 0.4445 & \\
\hline
\end{tabular}

Table 1 reports the mean and standard deviation of abnormal trading volume in December for depressed stocks and other stocks. A depressed stock is one with a closing price on the last trading day of November that is 10, 20, or 30 percent below the average price so far that year. The two-sided $p$ values are for a difference-in-means $t$-test comparing the mean abnormal volume for Depressed and Other stocks.

Table 2. December Returns, Depressed and Other Stocks

\begin{tabular}{|c|c|c|c|c|}
\hline & Number of Stocks & Mean & Standard Deviation & Two-sided $\mathrm{P}$ value \\
\hline \multicolumn{5}{|c|}{10 percent cutoff } \\
\hline Depressed Stocks & 320 & 1.5468 & 9.2558 & \multirow{2}{*}{0.8681} \\
\hline Other Stocks & 908 & 1.4523 & 7.0846 & \\
\hline \multicolumn{5}{|c|}{20 percent cutoff } \\
\hline Depressed Stocks & 178 & 1.5572 & 10.2942 & \multirow{2}{*}{0.8806} \\
\hline Other Stocks & 1050 & 1.4633 & 7.1812 & \\
\hline \multicolumn{5}{|c|}{30 percent cutoff } \\
\hline Depressed Stocks & 95 & 0.9076 & 10.3947 & \multirow{2}{*}{0.5723} \\
\hline Other Stocks & 1133 & 1.5246 & 7.4403 & \\
\hline
\end{tabular}

Table 2 reports the mean and standard deviation of the December returns for depressed stocks and other stocks. A depressed stock is one with a closing price on the last trading day of November that is 10, 20, or 30 percent below the average price so far that year. The two-sided $p$ values are for a difference-in-means t-test comparing the mean December returns for Depressed and Other stocks. 
Table 3. December Percent Returns, Fama-French Factors Plus Momentum

\begin{tabular}{|c|c|c|c|c|c|c|}
\hline \multirow[b]{2}{*}{ Variable } & \multicolumn{2}{|c|}{10 Percent Cutoff } & \multicolumn{2}{|c|}{20 Percent Cutoff } & \multicolumn{2}{|c|}{$30 \%$ Cutoff } \\
\hline & Depressed & Other & Depressed & Other & Depressed & Other \\
\hline Alpha & $\begin{array}{c}0.047 \\
(1.271)\end{array}$ & $\begin{array}{l}-0.009 \\
(0.549)\end{array}$ & $\begin{array}{c}0.080 \\
(1.578)\end{array}$ & $\begin{array}{l}-0.010 \\
(0.686)\end{array}$ & $\begin{array}{c}0.045 \\
(0.812)\end{array}$ & $\begin{array}{l}-0.007 \\
(0.475)\end{array}$ \\
\hline MKT & $\begin{array}{c}1.049 * \\
(25.140)\end{array}$ & $\begin{array}{c}0.863 * \\
(48.594)\end{array}$ & $\begin{array}{r}1.036^{*} \\
(18.373)\end{array}$ & $\begin{array}{c}0.881^{*} \\
(53.178)\end{array}$ & $\begin{array}{c}1.126^{*} \\
(18.088)\end{array}$ & $\begin{array}{r}0.932 * \\
(60.331)\end{array}$ \\
\hline SMB & $\begin{array}{l}-0.171^{*} \\
(2.368)\end{array}$ & $\begin{array}{c}-0.370^{*} \\
(12.074)\end{array}$ & $\begin{array}{l}-0.127 \\
(1.312)\end{array}$ & $\begin{array}{c}-0.339^{*} \\
(11.874)\end{array}$ & $\begin{array}{l}-0.181 \\
(1.678)\end{array}$ & $\begin{array}{r}-0.307^{*} \\
(11.524)\end{array}$ \\
\hline HML & $\begin{array}{c}0.100 \\
(1.205)\end{array}$ & $\begin{array}{c}0.143^{*} \\
(4.018)\end{array}$ & $\begin{array}{c}0.148 \\
(1.349)\end{array}$ & $\begin{array}{c}0.130^{*} \\
(3.936)\end{array}$ & $\begin{array}{c}0.174 \\
(1.398)\end{array}$ & $\begin{array}{r}0.150^{*} \\
(4.847)\end{array}$ \\
\hline WML & $\begin{array}{l}-0.427^{*} \\
(6.942)\end{array}$ & $\begin{array}{c}0.128^{*} \\
(4.893)\end{array}$ & $\begin{array}{l}-0.521^{*} \\
(6.263)\end{array}$ & $\begin{array}{c}0.059^{*} \\
(2.397)\end{array}$ & $\begin{array}{l}-0.554^{*} \\
(6.046)\end{array}$ & $\begin{array}{l}-0.014 \\
(0.599)\end{array}$ \\
\hline $\mathrm{R}^{2}$ & 0.551 & 0.778 & 0.462 & 0.810 & 0.400 & 0.847 \\
\hline
\end{tabular}

* two-sided $\mathrm{P}$ value $<0.05$

Table 3 reports the effects on the December portfolio returns of the value-weighted market return minus the Treasury bill rate (MKT), the return on three small portfolios minus the return on three large portfolios (SMB), the return on two value portfolios minus the return on two growth portfolios (HML); and the return on winner portfolios minus the return on loser portfolios (WML). The depressed stock portfolio is comprised of stocks with closing prices on the last trading day of November that were 10,20, or 30 percent below the average price so far that year. The (absolute) $t$ values are in parentheses below the estimated coefficients.

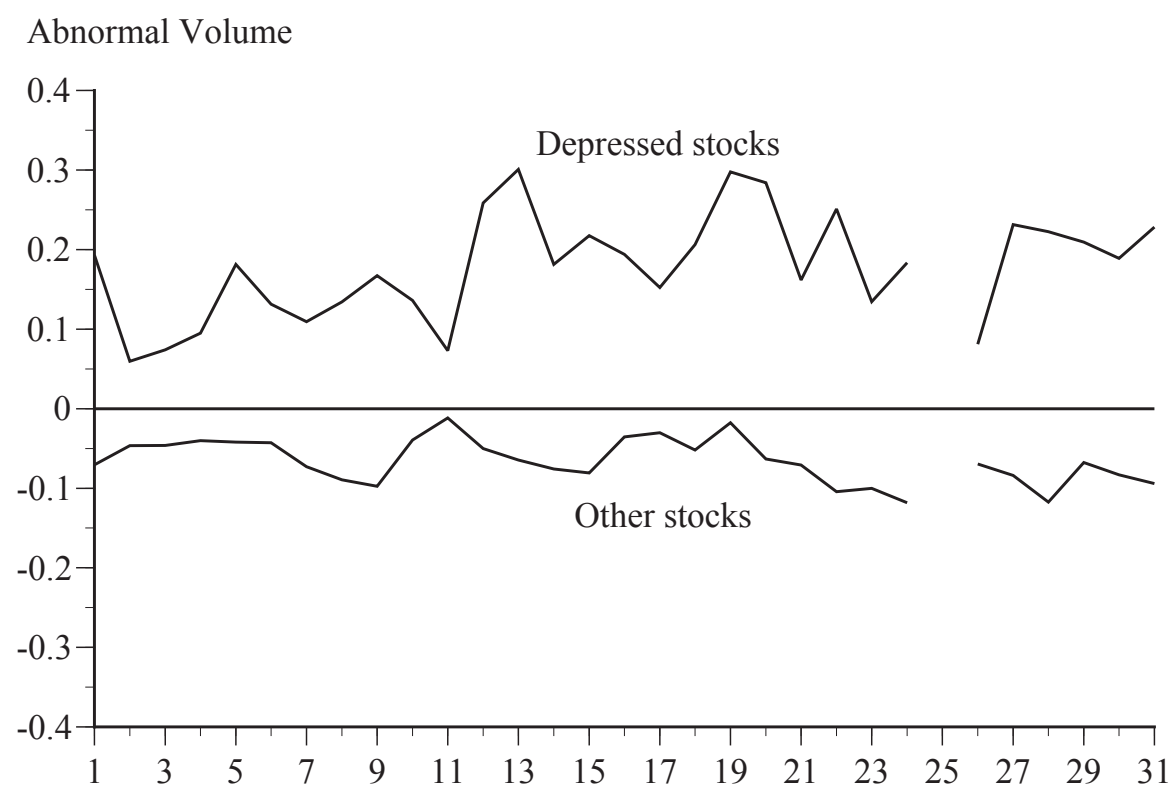

Figure 1. Average abnormal daily volume in December, 20 percent cutoff

Every day in December, the average abnormal volume was positive for Depressed stocks and negative for Other stocks. (There is a gap on December 25 because markets are closed on Christmas each year.) 